\title{
13 \\ Australia and the EU: Partners in the New Trade Agenda
}

\author{
Don Kenyon and Pierre van der Eng
}

The chapters in this book provide detailed analyses of several aspects of the new trade agenda, and the role of Australia and the European Union $(\mathrm{EU})$ in promoting it. The different context of the two entities in part determines their roles: the EU with its important influence in the Northern Hemisphere; and Australia with its focus on trade liberalisation in the Asia-Pacific region-the fastest growing region of the global economy.

Essentially, as the introduction and several chapters demonstrate, the new trade agenda is about the increasing integration of national and regional economies around the world. It is characterised by the shift away from tariffs and quotas as a major obstacle to global trade flows towards behind-the-border non-tariff barriers (NTBs). The exception here is in sectors such as agriculture, where the maintenance of domestic support in the form of governmental subsidies of one kind or another mandate the continuation of high levels of border protection.

Both Australia and the EU, therefore, are now set on a trade policy course with two objectives:

1. To conclude bilateral free trade agreements (FTAs) with key trading partners that focus increasingly on liberalising NTBs that currently go beyond the rules of the World Trade Organization (WTO), while continuing to work actively in Geneva for a successful outcome to the WTO's Doha multilateral trade negotiations; and 
2. To ensure that these 'new generation' or 'WTO-plus' FTAs will be a 'stepping stone' and not a 'stumbling block' (European Union 2006a: 8) to better WTO rules and more effective multilateral trade liberalisation into the future.

How could a new generation FTA between Australia and the EU advance these objectives? What progress towards these objectives has been achieved in the new-generation FTAs already negotiated by both Australia and the EU? This concluding chapter offers some tentative answers to both questions.

\section{Could an Australia-EU FTA produce meaningful liberalisation?}

First, a few facts to underline the significance of bilateral business relations. The EU of 28 member states is Australia's second-most important trading partner, following China, in two-way trade in goods and services. In 2014, with 18 per cent of the total, the EU constituted Australia's second-largest source of imports, behind China (21 per cent), but ahead of the United States of America (11 per cent). With 5 per cent of the total, the EU ranks third as an export market for Australia, behind China (33 per cent) and Japan (18 per cent) (DFAT 2015a). The EU is also Australia's largest two-way trade partner in services, accounting for 19 per cent of the total (DFAT 2015a) and it is Australia's largest source of inward direct investment, accounting for around 25 per cent of the total stock of foreign direct investment (ABS 2015). The EU, accounting for some 25 per cent of the global economy and more than 40 per cent of world trade in goods and services, is clearly a world economic and trade super power. In addition, the EU already has or is negotiating FTAs with many of Australia's major markets in Asia and with virtually all Australia's major trading partners that are members of the Organisation for Economic Co-operation and Development (OECD). These trade realities, therefore, make a good case for an Australia-EU FTA.

Second, a negative that has long overshadowed Australia-EU relations since the early 1970s relates to agricultural trade. As Murray (2005: 98-131) explained, the EU's common agricultural policy (CAP) has been an issue of continued contention between both entities over the 20 years that followed the accession of the United Kingdom (UK) to the then European Economic Community in 1973. The CAP and particularly 
the agriculture export policy of the EU-specifically the subsidised export of the so-called beef, butter, sugar and grains mountains onto the world market, which depressed global food prices and adversely affected Australia's rural exports around the world—were a major trade flashpoint between Australia and the EU. It has long been said that agriculture would therefore be a major obstacle to Australia negotiating an FTA with the $\mathrm{EU}$; that the continuing existence of the CAP would exclude agriculture being on the negotiating agenda.

This is now an outdated view. Australia's agricultural producers have found alternative export destinations, and are generally no longer dependent on the EU, as Murray and Zolin (2012) have demonstrated. More importantly, two developments have solved the fundamentals of this problem between Australia and the EU. First, the initial CAP reform package of 1992 and the agreement it led to on agriculture in the Uruguay Round of multilateral trade negotiations encompassed reductions on the use of export subsidies into the future; and second, the subsequent CAP reform packages from 1993 to 2003 continued the process of replacing high support prices to farmers in the EU with direct income supports. As the chapter by Daugbjerg and Swinbank in this book explains, these successive CAP reform packages reduced agricultural production in the $\mathrm{EU}$, reduced further the need for export subsidies in the EU and led ultimately to the offer of the EU in the Doha negotiations to eliminate export subsidies altogether (WTO 2008). Export subsidy elimination has now been implemented through decisions taken at the 10th WTO ministerial meeting in December 2015.

Access to the EU market for the temperate agricultural products that Australia continues to export to the world, however, remains a problem. This is largely as a result of the high levels of 'tariff equivalents' against agricultural imports that the EU was permitted to maintain at the end of the Uruguay Round negotiations in $1994 .{ }^{1}$ These tariff equivalents still operate as effective barriers against increased market access in the EU. The Doha negotiating process has, however, opened up opportunities to reduce the importance of this problem. Under the negotiating framework established by WTO in 2008, increased market access through expanded

1 During the Uruguay Round of multilateral trade negotiations, agreement was reached to convert all NTBs, including variable import levies in the EU, to tariff equivalents. As the high level of these tariff equivalents remained a significant barrier to imports, negotiated access to highly protected agricultural markets such as the EU was provided through tariff quotas at low or zero rates of duty. 
tariff quotas (TQs) at low import duty rates would be provided for all sensitive products on which high levels of tariff equivalents continue to apply (WTO 2008).

The Doha negotiations remain uncompleted but, as Gosper's chapter in this collection foreshadows, there appears to be no compelling reason why expanded TQs at low rates of import duty could not also provide improved access for Australia's agriculture exports to the EU market in FTA negotiations. The EU has already signalled its readiness in Geneva to negotiate on improved TQ access. No doubt, agriculture-related trade interests of the EU, such as treatment accorded to genetically modified products (GMOs), recognition of an expanded list of geographic indications (GIs), and sanitary and phytosanitary regulations would also be on the negotiating agenda. Agriculture, therefore, while both an essential and difficult subject for both sides in a new-generation FTA negotiation between Australia and the EU-as it was recently in the Comprehensive Economic and Trade Agreement (CETA) negotiations with Canada, as Elijah's chapter in this volume discusses-need not be the deal-breaker it would have been in earlier years.

Where would the major benefits of a new-generation FTA between Australia and the EU lie? Improved EU market access for Australia's beef, grains, sugar, dairy products and lamb would be a big positive for Australia. It would do much to defuse an issue that has dogged the relationship since the 1960s, as mentioned above. More broadly, a new-generation FTA could go a long way towards liberalising behind-the-border regulatory NTBs across the broad spectrum of agriculture, services and manufactures trade between the EU and Australia. Two factors in particular could be important in realising such an objective in negotiations. Both Australia and the EU have well-developed regulatory standards and enjoy high equivalence of regulatory intent. This could open the way for mutual recognition of technically different but broadly equivalent standards that impact on trade across a wide range of products and services.

The importance of bilateral services trade between the EU and Australia is discussed at greater length in Kerneis's chapter. In 2014, the EU was both Australia's largest export market for services with 16 per cent of the total and the largest source of imports of services into Australia with 23 per cent of the total (DFAT 2015a). In the recent CETA negotiations, the EU agreed to the liberalisation of services trade according to the 'negative-listing' approach (European Commission 2014). Under this 
approach, commitments are taken on all services in bilateral trade, apart from those inscribed on a specific exceptions list. This is the first time in any trade negotiation that the EU has conceded the negative-listing approach to services liberalisation. ${ }^{2}$ It is, however, the approach typically taken by Australia in its FTA negotiations. Now that the EU has taken the negative-listing approach with Canada, it is difficult to envisage it taking a less liberalising approach in future FTA negotiations, at least with any of its other OECD trading partners. The application of the negative-listing approach to services trade liberalisation in an FTA negotiation between Australia and the EU would be an important mutually beneficial gain, opening up the opportunity for the further expansion of trade in what is already the fastest growing area of bilateral trade.

In important specific areas of bilateral services trade between Australia and the EU, such as business and professional services, mutual recognition of broadly equivalent but technically divergent licensing and certification regulations could play an important trade-creating role in a new generation Australia-EU FTA. Even more important benefits would come from the mutual recognition of divergent but broadly equivalent professional qualifications requirements. Again, important steps towards liberalisation on this basis have been taken in the context of the CETA negotiations, which could provide a basis for a comparable outcome between Australia and the EU.

Average tariffs on non-agricultural goods are now low, at just 3 per cent in Australia and 4.2 per cent in the EU in 2014 (WTO 2015a). So there would appear to be little danger of serious trade diversion from differential tariff rates in an Australia-EU FTA, as Rollo (2011) substantiated. On the other hand, mutual recognition and/or harmonisation of standards would be trade-creating by neutralising the trade impact of regulatory divergences impacting on an expanding range of goods traded bilaterally between Australia and the EU. Current examples include food standards, packaging and labelling standards, sustainable production and environmental standards, and differing product standards on an increasingly wide range of semi-manufactured goods or components involved in intra-industry trade between Australia and the EU (Rollo 2011). There would also be practical trade benefits to both sides from reducing the negative trade and

2 In all previous FTA negotiations, including that with Korea discussed by Kang in this volume, the EU has taken the less liberal 'positive-listing' approach to services negotiations under which commitments are taken only on those services and services sectors included on a specific list. 
investment impact of divergent regulations that affect public procurement policies (especially at a sub-member state level in the EU and at subfederal level in Australia), competition policies, and investment restriction and protection policies.

Apart from agriculture, therefore, Australia-EU FTA negotiations could be even more focused than the CETA negotiation was on breaking new ground in the liberalisation of NTBs relevant to key areas that need to be resolved under the new trade agenda identified in Chapter 1. Such negotiations could play a role in advancing the twofold trade policy objectives espoused by both Australia and the EU; that is, liberalising NTBs through a bilateral FTA while ensuring that such liberalisation acts as a stepping stone rather than a stumbling block to strengthening the WTO, and enhancing scope for more effective multilateral negotiations on NTB issues into the future.

\section{Meeting the challenges of the new trade agenda}

As noted in Chapter 1, global trade rules dealing with NTBs, notably under the General Agreement on Tariffs and Trade (GATT) and since 1995 under WTO, have developed only slowly. Limited progress was made through the Tokyo Round of GATT negotiations (1973-79) in negotiating 'codes' to discipline NTBs such as anti-dumping and countervailing measures taken by governments against imports and the plurilateral 'Understanding on Government Procurement'. But, with reference to the exceptions rule in Article XX of the GATT, there were no limitations on the restrictions that importing countries could impose on services imports in terms of, for example, licensing and professional qualifications, and on goods imports in terms of, for example, technical standards and sanitary and phytosanitary import barriers.

Significantly more progress was made in this respect during the Uruguay Round (1986-94) with the General Agreement on Trade in Services (GATS) and the 'Technical Barriers to Trade' and 'Sanitary and Phytosanitary' agreements. Nevertheless, in the light of subsequent experience, the shortcomings of these agreements-particularly regulations limiting the supply of traded services; technical standards for manufactured and processed food products; and sanitary and phytosanitary regulations on imports-have become evident. 
Domestic regulations on licensing, certification and professional qualifications are part of the behind-the-border decisions (both at governmental and professional association levels) that determine international trade flows of traded services. National and/or regional divergences in such regulatory decisions produce the NTBs that limit trade flows in services. The domestic regulation article of GATS (Article VI) determines that regulatory decisions '[shall] not constitute unnecessary barriers to trade [and] ... [shall] not [be] more burdensome than necessary to ensure the quality of the service' (WTO 1994). This 'necessity clause' in GATS is mirrored by a similar provision in Article 2 of the Technical Barriers to Trade Agreement that is part of the Uruguay Round Agreements of 1994; namely, 'technical regulations shall not be more trade-restrictive than necessary to fulfil a legitimate objective' (WTO 1994). Similar provisions are also to be found in the Sanitary and Phytosanitary Agreement of 1994, where Article 5 contains a comparable 'necessity test' to those in the GATS and the Technical Barriers to Trade agreements, as well as a requirement to base import restrictions on 'risk assessment' to 'human, animal or plant life and health' (WTO 1994). These agreements also all contain provisions encouraging mutual recognition as a solution to regulatory divergences, especiallyit appears-in circumstances where there is a high level of equivalence of regulatory intent.

These principles are all aimed at reining in the NTB effect of regulations governing the supply of services, technical standards applying to goods, and conditions aimed at limiting import restrictions in defence of sanitary and phytosanitary standards. They are ground-breaking provisions, clearly aimed at tackling behind-the-border NTBs. In practice, however, operationalising them into meaningful multilateral trade rules that can be enforced in future trade liberalisation negotiations has proven to be a challenging and so far incomplete task. The disciplinary provisions of the Sanitary and Phytosanitary Agreement in particular have been the subject of 42 separate dispute settlement cases under the tough rules of the WTO Dispute Settlement Understanding since the conclusion of the Uruguay Round (WTO 2014a). So, apart from the use of the Dispute Settlement Understanding to put flesh on the bones of the Sanitary and Phytosanitary disciplinary provisions, operationalising the 'necessity tests' of the GATS and Technical Barriers to Trade agreements have not proceeded far in WTO. In that light, what may recent FTAs negotiated by both the EU and Australia have achieved? 


\section{(a) Plurilateral and bilateral}

Before answering this question, it is useful to briefly discuss the respective experiences of the EU and Australia, and of Australia and New Zealand, in seeking to deal with their regulatory divergences and resulting NTBs. In particular, the efforts of EU member states to do so in the context of creating the EU single market, of the states of Australia in creating a more integrated national entity, and of Australia and New Zealand in the context of the Closer Economic Relations (CER) agreement across the Tasman Sea.

Compared to the latter two cases, the experience of the EU is certainly of longer duration and has, over time, become more complex as the organisation grew from six original member states at comparable levels of economic development in 1957 to today's far more economically heterogeneous collection of 28 member states. During many years, the EU sought to deal with divergent technical product standards within individual member states through a painstaking process of harmonising standards. Following the Single European Act 1986, the EU shifted its focus to an 'equivalence' or mutual recognition approach in the creation of the single market in the EU during the 1990s. This was largely based on the Cassis de Dijon judgment of the European Court of Justice (1979), which found that goods lawfully produced in one EU member state cannot be banned from sale on the territory of another EU member state, even if they are produced with different technical or quality specifications. Over time, however, the enlargement of the EU reduced the levels of equivalence and trust among member states, and therefore the option of automatic acceptance of regulatory heterogeneity. Consequently, the EU has moved back towards attempting to fix detailed technical and environmental product standards on an EU-wide basis and seeking acceptance of its harmonised regulatory standards in FTAs negotiated with third countries (Messerlin 2011).

The experience inside Australia, and also between Australia and New Zealand, has been different. Concerned by continuing regulatory divergences between the states of Australia on product standards and also influenced by the Cassis de Dijon judgment and the EU's singlemarket drive through the 1990s, the Australian government of the day implemented the mutual recognition agreement (MRA) between the Australian states and territories from 1992, and in 1997 extended this to the Trans-Tasman Mutual Recognition Arrangement (TTMRA) with 
New Zealand. The TTMRA therefore became the first international trade agreement for the mutual recognition of standards. It covered not only product standards (on an unconditional but 'with exceptions' basisthat is, a negative-listing approach) but also the mutual recognition of professional qualifications standards between Australia and New Zealand (Hussey \& Kenyon 2011).

In its continuing efforts to deal with regulatory divergences between member states, the EU has embarked on a more recent and hopefully more enduring experiment in mutual recognition in its efforts to complete the EU single market in the services sector. The EU's 2006 Services in the Internal Market Directive, which aimed originally to implement an unconditional form of mutual recognition for a wide range of business and professional services across the $\mathrm{EU}$, had a long and difficult gestation going back to the mid-1990s.

Member state negotiations over the provisions of the directive coincided with the erosion of trust within an expanding EU— to take in a growing number of former Warsaw Pact countries-to accept as 'equivalent' divergent licensing provisions in different member states for a wide range of traded business services. The outcome was a compromise based on a concept known as mutual evaluation. The mutual evaluation concept in the directive is designed to operate as a peer-review process undertaken by member state authorities. If the divergent regulation is found to be comparable in regulatory intent, mutual recognition must be accorded (European Union 2006b). Mutual evaluation is therefore intended to operate as a managed form of mutual recognition.

How does the experience of the EU, Australia, and Australia and New Zealand in dealing with NTBs (or regulatory divergences) in technical standards for goods and in licensing provisions for services-either of the unconditional, negative-listing variety demonstrated by the TTMRA or the managed mutual evaluation variety present in the EU cross-border trade in services directive-relate to the broader application of the mutual recognition principle internationally? By granting recognition to the technically divergent regulations of another jurisdiction, the certifying state is effectively saying that those regulations meet acceptable standards, which implies a high level of equivalence of regulatory intent and a high level of trust between the jurisdictions. To a significant degree, this is likely to be the case between at least those countries that are currently members of the OECD. 
Past experience has shown that there are no significant problems between the states in Australia, or between Australia and New Zealand with the unconditional, negative-listing mutual recognition approach in both the MRA and the TTMRA. There do, however, appear to be problems with the mutual recognition of product standards among the 28 member states of the EU, mainly related to issues of trust across an increasingly economically heterogeneous membership (Messerlin 2011). Hopefully, the more managed form of mutual recognition present in the 2006 Services in the Internal Market Directive of the EU will work more effectively for the EU, and even between the EU and its trading partners in new-generation FTAs, and not just on services but on product and environmental (i.e. sustainable production) standards as well.

Against this background, what can some of the FTAs negotiated after 2006 tell us about progress made on liberalising NTBs? These are three examples:

1. The EU and Canada reached agreement in CETA on the recognition of professional qualifications, which appears to provide a successful example of the international application of the unconditional mutual recognition principle in so far as it provides for government-togovernment agreements, confirming consensus reached at professional levels on the conditions under which mutual recognition can be agreed. Guidelines for reaching consensus within specific professions are provided in CETA (European Commission 2014).

2. The Australia-Korea FTA provides for the establishment of a working group on professional services, charged inter alia with making recommendations on the mutual recognition of professional qualifications between Australia and Korea (DFAT 2014b: Chapter 7, Annex A). Similar provisions exist in the Australia-Japan FTA (DFAT 2014a). These could open the door to the eventual liberalisation of professional services trade comparable to that contained in CETA. However, as these provisions are formulated in the current agreements Australia has negotiated, they are less definitive than the provisions in CETA.

3. All three agreements above provide for cross-border trade in services commitments to be made on a negative-listing basis. This represents a significant expansion of the 'national treatment' commitments so far negotiated under GATS, as all tradeable services under these FTAs are subject to commitments to maintain the same regulatory treatment 
on imports as for domestic service providers. In WTO terms, such 'bindings' are considered valuable as parties to the agreement are protected (in effect multilaterally and not just bilaterally) from discriminatory treatment. Even if there is not a great deal or any actual trade liberalisation, this commitment operates as an effective ceiling on the NTB effect of regulations impacting on tradeable services.

Outside the areas of services and the scope of the WTO's Technical Barriers to Trade and Sanitary and Phytosanitary agreements, post2006 FTAs negotiated by the EU have broken beneficial new ground in the liberalisation of other NTBs generated by new trade agenda issues. One example is the chapter on public procurement in CETA. The existing plurilateral agreement in the WTO concerns competitive tendering of procedures for public procurement contracts. Currently, 67 WTO member states are either full members or have observer status in this WTO agreement. In practice, the tendering procedures of this WTO agreement apply primarily to the agencies of central governments that are actual signatories to this agreement. The new ground broken by CETA is to apply agreed tendering procedures to sub-federal and regional government authorities both within the EU and Canada. It therefore provides a useful expansion of agreed disciplinary provisions to a broader range of public purchasing authorities (European Commission 2014).

Similarly, on investment policy some progress is being made. CETA raises the threshold to $\mathrm{C} \$ 1.5$ billion under which foreign direct investment from the EU into Canada will no longer be subject to review under the Investment Canada Act. In both the FTAs negotiated by Australia with Korea and Japan, the threshold under which foreign investments will not be subject to prior screening by the Australian Foreign Investment Review Board has been raised to $\mathrm{A} \$ 1$ billion. CETA also contains specific provisions for the conduct of investor-state dispute settlement (ISDS) as well as investment protection rules (Government of Canada 2013).

On competition policy, CETA incorporates specific competition policy provisions relating especially to disciplinary provisions applying to monopolies, including monopoly state-owned enterprises. Similarly, the EU-Korea FTA contains a competition policy chapter setting out competition policy principles governing the conduct of monopolies and public enterprises, as well as the control of restrictive business agreements and subsidies, transparency, dispute settlement and the relationship between the FTA chapter and the provisions of the WTO 
(European Union 2011: Chapter 11). On product standards issues, the EU-Korea FTA made progress through the identification of Korean equivalents to the motor vehicle parts standards of the United Nations' Economic Commission for Europe. In the case of electronic goods and electrical appliances, the agreement reduced the scope of thirdparty certification by implementing the use of 'supplier's declaration of conformity'. In the EU-Singapore FTA, the chapter by Elms in this book finds that Singapore agreed to recognise EU standards and testing regimes for cars and car parts and that there was agreement on using international standards where possible in the electronics sector. Progress on resolving differences in technical barriers to trade more generally appears to have been left primarily to future regulatory cooperation within this FTA.

Based on the preliminary assessment above, it is possible to conclude that some progress on liberalising NTBs in recent FTAs has been made. CETA is the outstanding example. It also appears that more progress is being made on services, through negative-listing commitments and mutual recognition of qualifications on professional services; investment policy; public procurement, through the deepening of commitments to open tendering and transparency to sub-national purchasing authorities; and possibly also on competition policy, than on the standards and licensing NTBs that are the subject of the WTO Technical Barriers to Trade agreement and the GATS agreement on services. On standards and licensing issues, apart from the limited progress that seems to have been made through the harmonisation of divergent product standards in the EU-Korea and EU-Singapore FTAs, substantive treatment of divergent regulatory standards impacting on goods and services trade appears limited to chapters on regulatory cooperation. These chapters provide essentially for consultations aimed at encouraging greater convergence between the parties on future regulatory decisions expected to impact on trade.

The experience of both Australia and the EU internally, and their respective experience in recent FTA negotiations with others, gives rise to expectations that 'trade friendly' mutual recognition solutions to the many issues of standards and licensing raised above will be worth exploring in forthcoming Australia-EU FTA negotiations. The range of problems is likely to include mutual recognition of qualifications on traded professional services, such as architectural and engineering services; licensing and certification requirements on other traded services, including a wide range of business services; food, packaging and labelling standards; and sustainable production and environmental (e.g. biodiversity) standards; 
as well as technical standards on a growing range of semi-manufactured parts and components that are traded in global supply chains, and motor vehicle standards, which are of increasing interest to the EU. Mutual recognition solutions along the lines of CETA on professional services qualifications could be explored.

An alternative to mutual recognition could be the more involved managed mutual recognition approach envisaged by the $\mathrm{EU}$ in, for example, the EU's 2006 Services Directive. As a consequence of this Directive, individual member states are permitted to maintain regulations on traded services in defence of 'public policy, public security, public health and the protection of the environment' (Article 16), but only through a peer-review process through which it can be demonstrated that such measures are 'non-discriminatory' against imports and necessary and 'proportionate' to the requirements of the conditions specified (European Union 2006b). There is no reason why this managed mutual recognition approach should be restricted to tradeable services between the EU member states. Its extension to a broader range of regulatory NTBs in future FTA negotiations could yield worthwhile results in reducing the NTB effects of many standards issues on both goods and services trade.

\section{(b) Multilateral}

It is possible to conclude, at least provisionally, that some of the outcomes that are emerging from recent FTA negotiations conducted by both the EU and Australia in areas such as undertaking services commitments on a negative-listing basis, mutual recognition of professional services qualifications, public procurement, investment and competition policy could well be useful as eventual stepping stones to more effective current WTO disciplinary provisions and possibly future WTO negotiations on some NTB issues. Nevertheless, this is an issue that requires further detailed study.

In considering how NTBs related to regulatory divergences on traded goods and services could be liberalised multilaterally, it may be helpful to consider existing WTO agreements. In particular, how operationalisation of the 'necessity clauses' of both GATS (Article VI) and the Technical Barriers to Trade agreement (Article 2) could be a stepping stone to stronger WTO rules and future multilateral trade liberalisation. 
Progress might be made (as indicated above) by the wider use of the mutual evaluation approach to a more managed form of mutual recognition in reducing the NTB effect of regulatory divergences on technical standards for goods and services. Progress has already been made with the mutual recognition agreement on professional services qualifications in CETA and GATS, while both the WTO Technical Barriers to Trade and WTO Sanitary and Phytosanitary agreements have their separate provisions on according equivalence or mutual recognition wherever feasible. However, as noted above, mutual recognition solutions to problems of technical barriers to trade generated by the new trade agenda rely on high levels of equivalence of regulatory aims and objectives, and even more so on a high level of trust in the regulatory governance of different trading partners. Mutual recognition solutions will therefore always be problematic where these elements are lacking. What other options might be available, therefore, for use between trade partners that are part of a broader, more heterogeneous group in the context of plurilateral or multilateral discussions?

One obvious option would be to attempt to arrive at a set of 'horizontal' disciplinary provisions that expand the provisions of GATS and possibly the WTO Technical Barriers to Trade agreement. In relation to GATS, such work would be aimed at developing criteria relating to licensing, qualifications and technical standards requirements in an effort to operationalise the necessity test of GATS. Work on this task has in fact been conducted within WTO for some years now, but without yielding useful results. The horizontal disciplinary provisions route therefore does not appear to present well as a viable option.

A more productive option could be through the Trade in Services Agreement (TiSA) negotiations that are currently taking place in Geneva. TiSA is a negotiation between 53 developed and developing members of WTO (counting the 28 members states of the EU separately) aimed at the further liberalisation of trade in services. Negotiations began in April 2013 to seek an agreement that is compatible with GATS and that will 'support and feed back into multilateral trade negotiations' (DFAT 2015b: 18). As well as arriving at additional commitments across 'all services sectors', TiSA aims at developing new disciplinary provisions (trade rules) on, inter alia, 'domestic regulation to ensure regulatory settings do not operate as a barrier to trade in services' (DFAT 2015b: 18). According to the Australian Department of Foreign Affairs and Trade, 'positive progress' has been made on developing new trade rules on 
domestic regulation at recent rounds of TiSA negotiations in 2014 and 2015 (DFAT 2015c). This could be a promising sign. By November 2016, 21 negotiating rounds had been held but agreement had not yet been reached.

A still more fruitful option, and one for which there is precedence, could be the 'sectoral' or vertical approach. The existing stand-out example here is the WTO's 1998 Reference Paper on Basic Telecoms. It sets out common guidelines for a regulatory framework aimed at supporting the transition of the telecommunications sector from state monopolies to a competitive international market. These principles encompass competitive safeguards, interconnection, universal service, allocation and use of scarce resources, and the existence of independent regulators unencumbered by government controls. Some 60 WTO members are signatories to this reference paper. While the paper is as much about competition policy as it is about setting a regulatory framework for the telecommunications sector, it does provide a model of regulatory guidelines and best practice that could be adapted to the needs of other traded services on a sectoral basis applying across the broad spectrum of WTO membership (WTO 2014b).

Another example is a separate sectoral agreement in the information technology (IT) sector: the WTO's 1996 Information Technology Agreement (ITA), which was recently renegotiated and expanded. The 53 WTO members involved in the ITA negotiations have agreed to eliminate tariffs on a most-favoured-nation (MFN) basis on IT products, which currently account for 10 per cent of global trade. The new agreement also includes a commitment to identify solutions to NTBs in the IT sector (WTO 2015b).

New disciplinary provisions being negotiated in the TiSA process also include financial services, information and communications technology services, professional services, maritime transport services, air transport services, delivery services, energy services and public procurement. New opportunities for sectoral regulatory frameworks of broader plurilateral and multilateral application may therefore also emerge from this process.

A final option that might be considered could be an attempt to develop conceptual tools on the operation of standards of goods, licensing provisions and qualifications conditions in services that may be utilised on a case-by-case basis; in particular by groupings of countries that are at different stages of economic development and that span different parts 
of the world. This approach could have linkages to the mutual evaluation concept in the EU's 2006 Services Directive and to the principles of nondiscrimination, necessity and proportionality used in developing the EU's single market in goods and services. Peer review, efforts to encourage equivalence and build trust, as well as research into appropriate dispute settlement options could be a part of this current outlier option for seeking to deal with the NTB effect of divergences in standards and licensing arrangements that apply to traded goods and services.

\section{Conclusion}

Over the last more than 20 years the new trade agenda has become the focus of trade liberalisation. Bilateral and plurilateral agreements are increasingly aimed at liberalising behind-the-border regulatory NTBs that impact on services trade (such as licensing and certification requirements); trade in goods, particularly trade in semi-manufactures within global supply chains (divergent technical standards); foreign direct investment flows; public purchasing tender processes; and competition policy issues.

The EU and Australia are pursuing similar objectives in FTA negotiations. The outcome of the GATT Uruguay Round achieved much to defuse the long-standing conflict over agricultural trade policy. This outcome, together with accompanying domestic economic reforms, resulted in the EU and Australia emerging as partners. Both continue to pursue further multilateral trade liberalisation in relation to manufactures, services and the full range of new trade agenda issues. Australia and the EU were partners pursuing a new round of multilateral trade negotiations that opened in 2002 at the WTO Doha Round. Both have been disappointed with the failure to bring the Doha Round to a successful conclusion. A contributing factor in the failure of Doha to achieve acceptable outcomes has been the continuing weakness of GATT rules to discipline NTBs that resulted from issues that are now part of the new trade agenda.

In light of sustained delays in the completion of the Doha Round, the EU and Australia have pursued bilateral and plurilateral FTAs that aim (a) to liberalise NTBs in ways that go beyond the current rules of the WTO, and (b) to ensure that these new 'deep integration' or 'GATT-plus' FTAs will be stepping stones rather than stumbling blocks to better WTO rules and to more effective multilateral negotiations into the future. 
Some progress in creating such stepping stones to a better WTO has been made in recent FTAs negotiated by both Australia and the EU. The standout example to date is CETA between the EU and Canada. But stepping stones can also be identified in the FTAs Australia has negotiated with Korea and Japan, as well as in the FTAs that the EU has concluded with Korea and Singapore. In these agreements, most progress has been made in relation to services. For example, through commitments to the use of a negative-listing approach and the mutual recognition of professional qualifications. Progress has also been made on public procurement by expanding competitive tendering to the enterprises of sub-federal and regional authorities, on investment, through the relaxation of investment restrictions, and through convergence of competition policy principles. Much less progress has been made in dealing with the trade impact of divergent product standards and licensing requirements. These remain major NTBs in goods and services trade. For the most part, signatory countries rely on regulatory cooperation to deal with these issues in order to overcome future problems.

Of the possible future solutions in this respect, mutual recognition remains the clearest and simplest instrument for dealing with diverging standards and licensing requirements in a way that accommodates already existing agreements in WTO. This is underlined by the EU's experience with the creation of the single market, and Australia's experience with the creation of the 1992 mutual recognition agreement between the Australian states, and the subsequent extension of the principle to New Zealand under the Trans-Tasman Mutual Recognition Agreement, as this chapter has argued.

The chapter also stressed that mutual recognition requires high levels of equivalence of regulatory intent, capacity and trust. These conditions are not always present between potential FTA partners and may need to be nurtured. However, as this chapter has argued, strong foundations for the underlying requirements of mutual recognition exist in the current trade and business relations between Australia and the EU. With the required will and effort, it seems likely that negotiations towards an Australia-EU FTA will make better progress on mutual recognition solutions to divergent standards and licensing NTBs than has been the case in the other FTAs that they have recently negotiated. A significant conclusion of this chapter is therefore that an Australia-EU FTA is likely to be a significant stepping stone to better WTO rules and outcomes into the future. 
This chapter also canvassed mechanisms through which WTO-friendly solutions applicable to a broader range of WTO members might be found to behind-the-border NTBs. It raised options to resolving this, including horizontal solutions, the most promising of which is the TiSA negotiation on services trade liberalisation between 53 developed and developing countries currently being pursued in a WTO context. Vertical or sectoral approaches also merit attention, as the discussion of the Reference Paper on Basic Telecoms and the agreement to liberalise information technology trade indicated.

Finally, the chapter has argued that scope exists for further research into the ways in which the principles that underlie existing WTO agreements for the purpose of disciplining NTBs-such as 'non-discrimination', 'necessity' and 'proportionality'-could be defined and developed into conceptual tools that would be of more practical use in future trade negotiations aimed at liberalising behind-the-border NTBs. All these options for the development of mechanisms for liberalising NTBs merit further attention, consideration and research.

As a postscript to this chapter and to the book as a whole, the UK voted in a national referendum on 23 June 2016 to leave the EU. The UK implemented Article 50 of the Treaty on European Union (the exit clause) that started a two-year period of negotiations on the terms of its departure from the EU on 28 March 2017. Whatever the outcomes of this process will be, the opportunities remain for Australia and the EU to be partners in advancing the new trade agenda.

\section{References}

ABS (Australian Bureau of Statistics) (2015), 'International Investment Position, Australia: Supplementary Statistics, 2014. Cat No. 5352.0’ (Australian Bureau of Statistics: Canberra).

DFAT (Department of Foreign Affairs and Trade) (2014a), 'Japan-Australia Economic Partnership Agreement'. Available at dfat.gov.au/trade/ agreements/jaepa/official-documents/Pages/official-documents.aspx.

DFAT (2014b), 'Korea-Australia Free Trade Agreement'. Available at dfat. gov.au/trade/agreements/kafta/official-documents/Pages/default.aspx. 
DFAT (2015a), Composition of Trade: Australia, 2014 (Department of Foreign Affairs and Trade: Canberra).

DFAT (2015b), 'Productivity Commission Study into Barriers to Growth in Australian Services Exports: Submission by Department of Foreign Affairs and Trade (DFAT), Australian Trade Commission (Austrade), Export Finance and Insurance Corporation (Efic)'. Available at www.pc.gov.au/inquiries/current/service-exports/submissions.

DFAT (2015c), 'Trade in Services Agreement: News'. Available at dfat.gov.au/trade/agreements/trade-in-services-agreement/news/ Pages/news.aspx.

European Commission (2014), 'Draft of Consolidated CETA Text (Comprehensive Economic and Trade Agreement between Canada and the European Union)'. Available at trade.ec.europa.eu/doclib/ docs/2014/september/tradoc_152806.pdf.

European Union (2006a), 'Global Europe: Competing in the World' [COM(2006) 567] (European Commission: Brussels), last updated 20 May 2009. Available at eur-lex.europa.eu/legal-content/EN/ TXT/?uri=URISERV:r1 1022.

European Union (2006b), 'Directive 2006/123/EC on Services in the Internal Market', Official Journal of the European Union 49, L 376: $36-68$.

European Union (2011), 'Free Trade Agreement between the European Union and its Member States, of the one part, and the Republic of Korea, on the other part', Official Journal of the European Union 54, L127: 1-1426.

Government of Canada (2013), 'Technical Summary of Negotiated Outcomes: Canada-European Union Comprehensive Economic and Trade Agreement', October. Available at international.gc.ca/tradecommerce/assets/pdfs/ceta-technicalsummary.pdf.

Hussey, Karen \& Don Kenyon (2011), 'Regulatory divergences: A barrier to trade and a potential source of trade disputes', Australian Journal for International Affairs 65(4): 381-93. doi.org/10.1080/10357718. 2011.586668. 
Messerlin, Patrick (2011), 'The EU Single Market in Goods: Between mutual recognition and harmonisation', Australian Journal for International Affairs 65(4): 410-34. doi.org/10.1080/10357718.201 1.586019 .

Murray, Philomena (2005), Australia and the European Superpower: Engaging with the European Union (Melbourne University Press: Clayton, Vic.).

Murray, Philomena \& M. Bruna Zolin (2012), 'Australia and the European Union: Conflict, competition or engagement in agricultural and agri-food trade?', Australian Journal of International Affairs 66(2): 186-205. doi.org/10.1080/10357718.2011.646481.

Rollo, Jim (2011), 'The potential for deep integration between Australia and the European Union in Australia's trade with Europe: Potential unfulfilled', Australian Journal for International Affairs 65(4): 394-409. doi.org/10.1080/10357718.2011.586321.

WTO (World Trade Organization) (1994), Results of the Uruguay Round of Multilateral Trade Negotiations: The Legal Texts (GATT Secretariat: Geneva). Available at www.wto.org/english/docs_e/legal_e/legal_e.htm.

WTO (2008), 'Revised Draft Modalities for Agriculture', TN/AG/W/4/ Rev.4, 6 December. Available at www.wto.org/english/tratop_e/agric_e /chair_texts08_e.htm.

WTO (2014a), 'Disputes by agreement'. Available at www.wto.org/ english/tratop_e/dispu_e/dispu_agreements_index_e.htm?id=A19\#.

WTO (2014b), 'Negotiating group on basic telecommunications', 24 April 1996. Available at www.wto.org/english/tratop_e/serv_el telecom_e/tel23_e.htm.

WTO (2015a), 'World Tariff Profiles'. Available at www.wto.org/english/ tratop_e/tariffs_e/tariff_data_e.htm.

WTO (2015b), 'Information Technology Agreement'. Available at www. wto.org/english/tratop_e/inftec_e/inftec_e.htm. 
This text is taken from Australia, the European Union and the New Trade Agenda, edited by Annmarie Elijah, Don Kenyon, Karen Hussey and Pierre van der Eng, published 2017 by ANU Press, The Australian National University, Canberra, Australia. 